\title{
Neuroprotective Effects of Regulators of the Glycogen Synthase Kinase- $3 \beta$ Signaling Pathway in a Transgenic Model of Alzheimer's Disease Are Associated with Reduced Amyloid Precursor Protein Phosphorylation
}

\author{
Edward Rockenstein, ${ }^{1}$ Magdalena Torrance, ${ }^{1}$ Anthony Adame, ${ }^{1}$ Michael Mante, ${ }^{1}$ Pazit Bar-on, ${ }^{1}$ John B. Rose, ${ }^{1}$ \\ Leslie Crews, ${ }^{2}$ and Eliezer Masliah ${ }^{1,2}$ \\ Departments of ${ }^{1}$ Neurosciences and ${ }^{2}$ Pathology, University of California, San Diego, La Jolla, California 92093
}

\begin{abstract}
The glycogen synthase kinase-3 $\beta$ (GSK3 $\beta$ ) pathway plays an important role in mediating neuronal fate and synaptic plasticity. In Alzheimer's disease (AD), abnormal activation of this pathway might play an important role in neurodegeneration, and compounds such as lithium that modulate GSK3 $\beta$ activity have been shown to reduce amyloid production and tau phosphorylation in amyloid precursor protein (APP) transgenic ( $\operatorname{tg}$ ) mice. However, it is unclear whether regulation of GSK3 $\beta$ is neuroprotective in APP tg mice. In this context, the main objective of the present study was to determine whether pharmacological or genetic manipulations that block the GSK3 $\beta$ pathway might ameliorate the neurodegenerative alterations in APP tg mice and to better understand the mechanisms involved. For this purpose, two sets of experiments were performed. First, tg mice expressing mutant human APP under the Thyl promoter (hAPP tg) were treated with either lithium chloride or saline alone. Second, hAPP tg mice were crossed with GSK3 $\beta$ tg mice, in which overexpression of this signaling molecule results in a dominant-negative (DN) effect with inhibition of activity. hAPP tg mice that were treated with lithium or that were crossed with DN-GSK3 $\beta$ tg mice displayed improved performance in the water maze, preservation of the dendritic structure in the frontal cortex and hippocampus, and decreased tau phosphorylation. Moreover, reduced activation of GSK3 $\beta$ was associated with decreased levels of APP phosphorylation that resulted in decreased amyloid- $\beta$ production. In conclusion, the present study showed that modulation of the GSK3 $\beta$ signaling pathway might also have neuroprotective effects in tg mice by regulating APP maturation and processing and further supports the notion that GSK $3 \beta$ might be a suitable target for the treatment of AD.
\end{abstract}

Key words: lithium; Alzheimer's disease; APP; amyloid; GSK3 $\beta$; phosphorylation

\section{Introduction}

In recent years, considerable effort has been dedicated at developing new and more effective treatments for Alzheimer's disease $(\mathrm{AD})$, a leading cause of dementia in the aging population. Alzheimer's disease is characterized by widespread neurodegeneration throughout the association cortex and limbic system (Hof and Morrison, 1994), deposition of amyloid- $\beta$ protein $(\mathrm{A} \beta)$ in the neuropil (Jellinger and Bancher, 1998) and around blood vessels (Jellinger, 2002), and formation of intraneuronal neurofibrillary tangles (NFTs) (Trojanowski and Lee, 2000). The neurodegenerative process in $\mathrm{AD}$ consists of synaptic injury (DeKosky and Scheff, 1990; DeKosky et al., 1996; Masliah et al., 1997; Scheff and Price, 2003) and neuronal loss (Terry et al., 1981), followed by intense astrogliosis (Beach et al., 1989) and microglial cell proliferation (Rogers et al., 1988; Masliah et al., 1991).

Received Jan. 26, 2006; accepted 0ct. 27, 2006.

This work was supported by National Institutes of Health Grants MH62962, AG10435, AG022074, AG18440, AG11385, and AG05131.

Correspondence should be addressed to Dr. Eliezer Masliah, Department of Neurosciences, University of California, San Diego, La Jolla, CA 92093-0624. E-mail: emasliah@ucsd.edu.

DOI:10.1523/JNEUROSCI.4321-06.2007

Copyright $@ 2007$ Society for Neuroscience $\quad$ 0270-6474/07/271981-11\$15.00/0
Several lines of investigation support the notion that abnormal accumulation of products of the $\mathrm{A} \beta$ precursor protein (APP) metabolism might play a central role in the pathogenesis of $\mathrm{AD}$ (Tanzi et al., 1993; Selkoe, 1994; Selkoe et al., 1996). Although the precise mechanisms through which APP products might result in neurodegeneration in AD are not completely clear, recent studies suggest that alterations in signaling pathways involved in neuronal survival and synaptic plasticity play an important role. Among them, the glycogen synthase kinase- $3 \beta$ (GSK3 $\beta$ ) pathway might play an important role (Kaytor and Orr, 2002) because aberrant activation of this signaling molecule has been shown to modulate APP processing (Aplin et al., 1996; Ryder et al., 2003; Ryder et al., 2004) and tau phosphorylation (Mandelkow et al., 1992; Pei et al., 1999; Anderton et al., 2001). In the brains of AD patients and APP transgenic (tg) mice (Lucas et al., 2001; Ishizawa et al., 2003) altered localization of GSK3 $\beta$ is associated with NFT formation (Baum et al., 1996; Pei et al., 1997, 1999). In early stages, GSK3 accumulates with tau in neuritic plaques (Shiurba et al., 1996) and in the cytoplasm of pretangle neurons (Pei et al., 1997), whereas in mature NFTs, the colocalization with GSK3 is reduced (Baum et al., 1996; Harr et al., 1996; Shiurba et al., 1996). In addition, overexpression of active GSK $3 \beta$ results in an AD-like 
phenotype in tg mice (Brownlees et al., 1997), which can be reversed by turning off GSK $3 \beta$ expression under the regulatory control of a conditional promoter (Lucas et al., 2001; Engel et al., 2006).

Therefore, devising strategies that might interfere with the abnormal activation of this pathway might provide a promising new therapeutic approach for AD. Interestingly, the moodstabilizing agent lithium might protect against excitotoxicity by modulating the activity of GSK3 $\beta$ (Chalecka-Franaszek and Chuang, 1999; Chen and Chuang, 1999; Manji et al., 1999) as well as other pathways involved in neuronal survival, such as Bcl-2 (B-cell lymphoma protein 2) expression (Wei et al., 2001; Ghribi et al., 2002), inositol metabolism (O'Donnell et al., 2000; Williams et al., 2002), and mitogen-activated protein kinase signaling (Yuan et al., 1999). Furthermore, recent in vivo studies have shown that lithium reduces the $\mathrm{AD}$-like neuropathology. For example, lithium has been shown to reduce $A \beta$ production and amyloid plaque load in human (h)APP transgenic (tg) mice (Phiel et al., 2003; Su et al., 2004). Moreover, lithium and valproic acid have been shown to decrease tau phosphorylation in tau tg mice (Nakashima et al., 2005; Noble et al., 2005). However it is not known whether blocking GSK $3 \beta$ signaling is neuroprotective and ameliorates the performance deficits in the water maze in APP tg mice. In addition, the mechanisms through which GSK3 $\beta$ inhibitors are protective and reduce $\mathrm{A} \beta$ products are not completely clear.

In this context, the main objective of the present study was to determine whether pharmacological and genetic manipulations that block the GSK $3 \beta$ pathway are capable of reducing the neurodegenerative alterations in an hAPP tg mouse model that mimics certain aspects of AD (Rockenstein et al., 2001) and to better understand the mechanisms involved. We found that the neuroprotective effects of blocking GSK3 $\beta$ in vivo was associated with improved behavioral performance and a reduction of APP processing into amyloidogenic pathways by reducing APP phosphorylation.

\section{Materials and Methods}

Generation of $h A P P$, dominant-negative-GSK3$\beta$, and double $t g$ mice. For these experiments, tg mice expressing high levels of hAPP and GSK3 $\beta$ were used. The hAPP tg mice express mutated (London V717I and Swedish K670M/N671L) hAPP751 under the control of the murine (m)Thy-1 promoter (hAPP tg, line 41) (Rockenstein et al., 2001). This tg model was selected because mice produce high levels of $\mathrm{A} \beta_{1-42}$ and exhibit performance deficits in the water maze, synaptic damage, and plaque formation at an early age (beginning at 3 months). Transgenic lines were maintained by crossing heterozygous tg mice with nontransgenic (nontg) $\mathrm{C} 57 \mathrm{BL} / 6 \times \mathrm{DBA} / 2 \mathrm{~F} 1$ breeders. All mice were heterozygous with respect to the transgene.

For the generation of kinase inactive tg mice, wild-type GSK3 $\beta$ was overexpressed under the regulatory control of a neuronal promoter (mThy1). This results in a feedback loop mechanism that activates Akt, which in turn inactivates the excess GSK3 $\beta$ by phosphorylation at Ser9. For this reason, we denominate these mice dominant-negative (DN)GSK3 $\beta$ tg. Briefly, as described previously (Rockenstein et al., 2001, $2002 \mathrm{~b}$ ), for the generation of human DN-GSK3 $\beta$ tg mice, cDNA encoding wild-type GSK3 $\beta$ was produced by reverse transcriptase (RT)-PCR from human brain mRNA and inserted between exons 2 and 4 into the Thyl expression cassette (kindly provided by Dr. H. van der Putten, Ciba-Geigy, Basel, Switzerland), purified, and microinjected into onecell embryos (C57BL/6 $\times$ DBA/2 F1). The sequence of wild-type GSK3 $\beta$ was confirmed by PCR and sequencing analysis, and all mice were heterozygous with respect to the transgene. The cDNA includes a Kozak consensus sequence (GCC ACC ATG) at the $5^{\prime}$ end to enhance expression. The heterozygous DN-GSK3 $\beta$ tg founder mice were identified by
PCR analysis of genomic DNA extracted from tail biopsies and screened for RNA and protein levels of expression by ribonuclease protection assay (RPA) and Western blot, respectively. Because GSK3 $\beta$ inactivation, and reduced kinase activity, is conferred by phosphorylation at Ser9, mice displaying the highest levels of inactivated GSK3 $\beta$ (phosphorylated at Ser9) were selected for crosses with the hAPP tg mice as described previously (Rockenstein et al., 2002b). Single and double tg mice were maintained until 6 months of age, followed by testing in the water maze.

Treatment of hAPP $\mathrm{tg}$ mice with lithium chloride. To test the neuroprotective effects of lithium in a tg model of AD-like pathology, hAPP tg mice were treated with lithium chloride $(n=6)(20 \mathrm{mg} / \mathrm{kg}$, i.p., daily; Sigma, St. Louis, MO) or saline alone $(n=6)$ starting at 3 months of age for 3 months and tested (at 6 months of age) in the water maze. This long-term treatment period was selected to maximize the effects on amyloid production and behavior, and, in this context, a lower dose than in previous studies (Phiel et al., 2003; Noble et al., 2005) was used to prevent adverse effects of lithium buildup. On the last day of the testing period, mice were deeply anesthetized, and blood was obtained from cardiac puncture and placed in EDTA-treated tubes for determination of lithium levels. Tissue was harvested immediately after behavioral testing. Control experiments for the behavioral and immunoblot studies were performed with an additional group of 12 nontg mice ( 6 months old) that were treated simultaneously with lithium $(n=6)$ or saline alone $(n=6)$.

Water maze testing. Briefly, as described previously (Rockenstein et al., 2003), to evaluate the functional effects of GSK $3 \beta$ inactivation, groups of hAPP tg mice treated with lithium and crosses between hAPP and DNGSK3 $\beta$ tg mice were tested in the water maze, beginning with a training period that included $3 \mathrm{~d}$ exposure to the visible platform. Then mice were tested for learning and memory with the hidden platform for $4 \mathrm{~d}$, followed by one "visible test" trial and $1 \mathrm{~d}$ probe testing. We have shown previously that the performance deficits of the hAPP tg animal models are most likely related to the neurodegenerative changes and are not the result of abnormalities such as motor defects, anxiety, or visual alterations (Rockenstein et al., 2003, 2005a). All experiments described were approved by the animal subjects committee at the University of California at San Diego and were performed according to National Institutes of Health (NIH) recommendations for animal use.

Tissue processing. In accordance with NIH guidelines for the humane treatment of animals, mice were killed by deep anesthesia with chloral hydrate. Brains were removed and divided sagittally. One hemibrain was postfixed in phosphate-buffered $4 \%$ paraformaldehyde, $\mathrm{pH} 7.4$, at $4^{\circ} \mathrm{C}$ for $48 \mathrm{~h}$ and sectioned at $40 \mu \mathrm{m}$ with a Vibratome 2000 (Leica, Nussloch, Germany), whereas the other hemibrain was snap frozen and stored at $-70^{\circ} \mathrm{C}$ for RNA and protein analysis.

RNA analysis. Total RNA was extracted with TRI reagent (Molecular Research Center, Cincinnati, OH) from snap-frozen hemibrains or dissected brain regions (neocortex and hippocampus) and stored in formazol buffer (Molecular Research Center) at $-20^{\circ} \mathrm{C}$. RNA was analyzed by solution hybridization RPA, essentially as described previously (Rockenstein et al., 1995). Samples were separated on 5\% acrylamide/8 M urea Tris/borate/EDTA gels, and dried gels were exposed to Kodak XAR film (Eastman Kodak, Rochester, NY). mRNA levels were quantified from PhosphorImager readings of probe-specific signals corrected for RNA content/loading errors by normalization to $\beta$-actin signals (Rockenstein et al., 1995). The following ${ }^{32} \mathrm{P}$-labeled antisense riboprobes were used to identify specific mRNAs [protected nucleotides (GenBank accession number)]: hAPP [780-1009 nt (NM_000484)], human GSK3 $\beta$ [121359 nt (NM_002093)], murine GSK3 $\beta$ [197-393 nt (AF156099)], and murine $\beta$-actin [480-565 nt (X03672)].

Determination of APP levels, APP products, and A $\beta$-degrading enzymes. Levels of hAPP immunoreactivity were determined in brain homogenates by Western blot and in vibratome sections by immunocytochemistry, as described previously (Rockenstein et al., 2001, 2005a). For Western blot analysis, $15 \mu \mathrm{g} /$ lane of cytosolic and particulate fractions, assayed by the Lowry method, were loaded into 10\% SDS-PAGE gels and blotted onto nitrocellulose paper. Blots were incubated with antibodies against full-length (FL) APP (mouse monoclonal, clone 22C11, 1:20,000; Chemicon, Temecula, CA), A $\beta$ (mouse monoclonal, clone 6E10, 1:1000; Signet Laboratories, Dedham, MA), APP C-terminal fragments (CTFs) 
(rabbit polyclonal CT15, 1:2500; courtesy of Dr. E. Koo, University of California, San Diego, La Jolla, CA), phosphorylated APP (APP-p) (Thr668, 1:1200; Cell Signaling Technology, Beverly, MA), neprilysin (mouse monoclonal, clone CD10, 1:1000; Abcam, Cambridge, MA), or $\beta$-secretase 1 (BACE1) (1:1000; ProSci, Poway, CA), followed by secondary antibodies tagged with horseradish peroxidase (HRP) (1:5000; Santa Cruz Biotechnology, Santa Cruz, CA) and were visualized by enhanced chemiluminescence and analyzed with a Versadoc XL imaging apparatus (Bio-Rad, Hercules, CA). Analysis of actin levels was used as a loading control.

Determination of $A \beta$ levels by ELISA. Brain samples from the mouse cortex were homogenized in ice-cold buffer (5 m guanidine- $\mathrm{HCl}$ and PBS, pH 8.0) with $1 \times$ protease inhibitor cocktail (Calbiochem, San Diego, CA). Homogenates were then mixed for $3-4 \mathrm{~h}$ at room temperature and centrifuged at $16,000 \times g$ for $20 \mathrm{~min}$ at $4^{\circ} \mathrm{C}$. The resulting supernatants were diluted 10-fold in Dulbecco's PBS, pH 7.4, containing 5\% bovine serum albumin and $0.03 \%$ Tween 20. Quantification of the levels of $\mathrm{A} \beta_{1-42}$ was performed with a commercially available sandwich-type ELISA (Biosource International, Camarillo, CA).

Immunoblot analysis and kinase activity assay for GSK3 $\beta$. Briefly, as described previously (Hashimoto et al., 2002), levels of total (t-GSK3 $\beta$ ) (mouse monoclonal, 1:1000; Santa Cruz Biotechnology) and phosphorylated (GSK3 $\beta$-p) (Ser9, mouse monoclonal, 1:1000; Cell Signaling Technology) forms of GSK3 $\beta$ were determined by immunoblot. The antibody against GSK3 $\beta$-p identifies the inactivated kinase. In addition, to investigate the involvement of related pathways in GSK3 $\beta$ inactivation, levels of the following targets were determined by immunoblot analysis: phosphorylated Akt (Akt-p) (rabbit polyclonal, 1:700; Cell Signaling Technology), total Akt (t-Akt) (rabbit polyclonal, 1:1000; Cell Signaling Technology), protein phosphatase 1 (PP1) (mouse monoclonal, 1:1000; generously provided by Dr. Peter Davies, Albert Einstein College of Medicine, Bronx, NY) and three antibodies against phosphor-

A

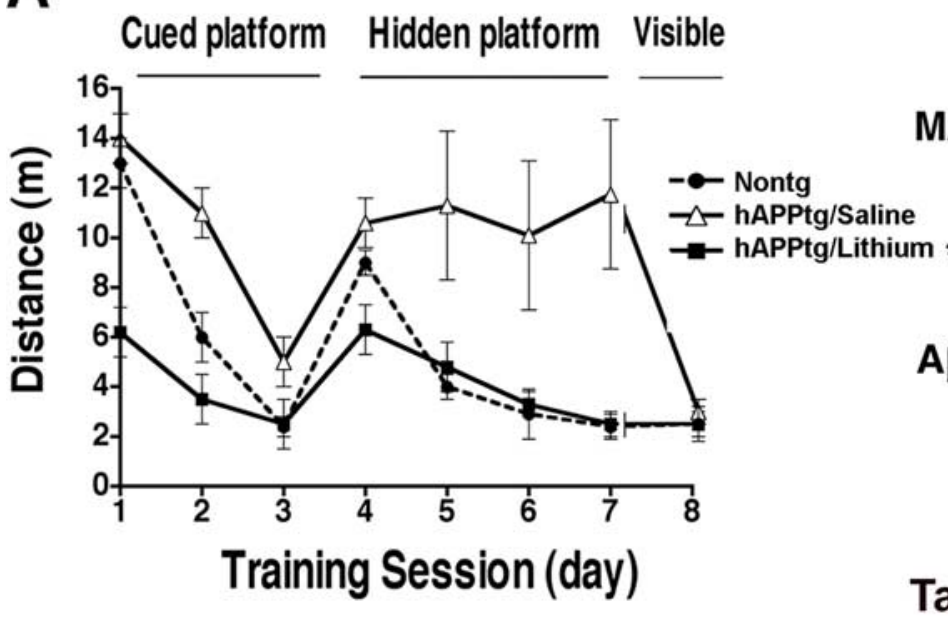

Nontg
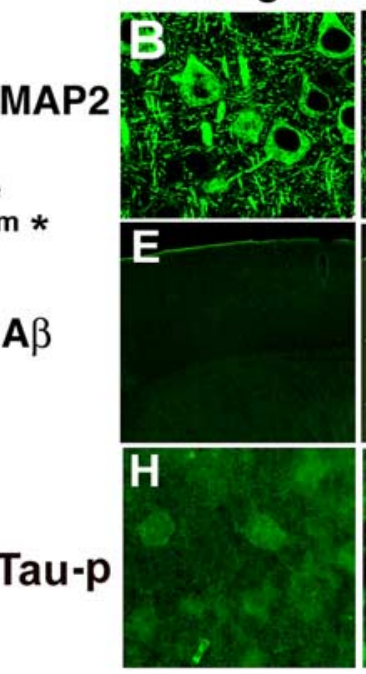

K

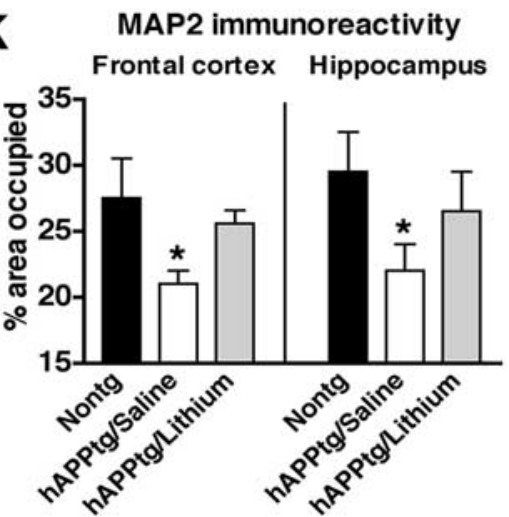

$\mathbf{L}$

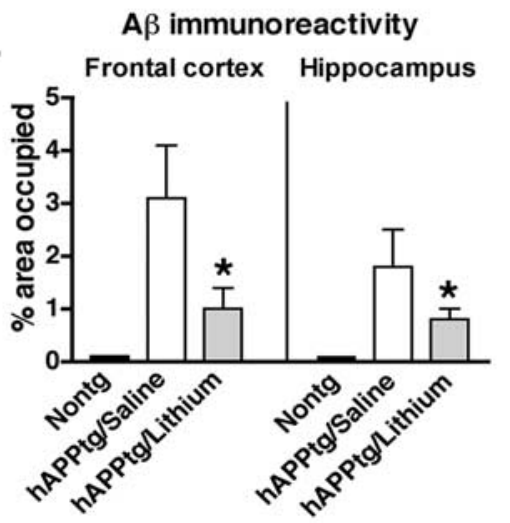

\section{hAPP tg}

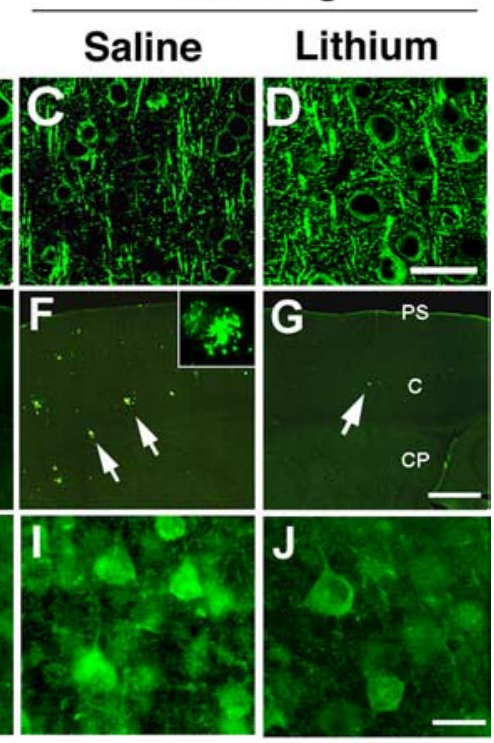

M

Tau-p immunoreactivity Frontal cortex Hippocampus

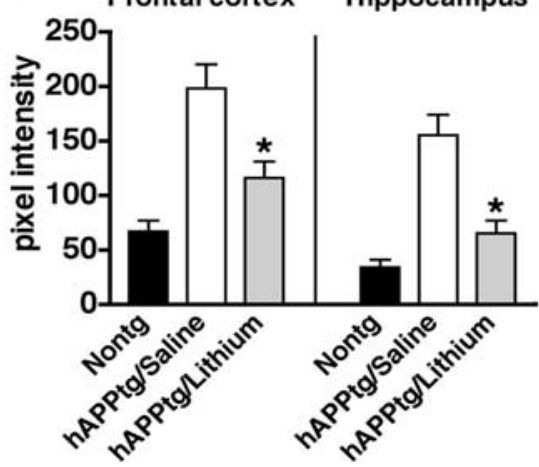

Figure 1. Effects of lithium treatment on water maze performance and neuropathology of hAPP tg mice. $A$, During the hidden platform portion of the water maze test, saline-treated hAPP tg mice showed performance deficits compared with the nontg saline-treated mice that were ameliorated by the treatment with lithium. $\boldsymbol{B}$, Laser scanning confocal microscopic image of MAP2 immunoreactivity in the frontal cortex of a nontg mouse. C, Decreased MAP2 immunoreactivity in the frontal cortex of a saline-treated hAPP tg mouse. D, Restored MAP2 immunoreactivity in the frontal cortex of a lithium-treated hAPP tg mouse. $\boldsymbol{E}$, Laser scanning confocal low-power microscopic image of the frontal cortex of a nontg mouse immunostained with an antibody against $A \beta$ (6E10). $\boldsymbol{F}$, Increased amyloid deposition and plaques (arrows) in the frontal cortex of a saline-treated hAPP tg mouse. Higher-power inset shows the morphology of an individual $A \beta$-immunoreactive plaque. $\boldsymbol{G}$, Reduced $A \beta$ immunoreactivity in the frontal cortex of a lithium-treated hAPP tg mouse immunostained with an antibody against A $\beta$. PS, Pial surface; $C$, cortex; $C P$, caudoputamen. $\boldsymbol{H}$, Laser scanning confocal microscopic image of tau-p immunoreactivity in the frontal cortex of a nontg mouse. $I$, Increased tau-p immunoreactivity in the frontal cortex of a saline-treated hAPP tg mouse. $\boldsymbol{J}$, Reduced tau-p immunoreactivity in the frontal cortex of a lithium-treated hAPP tg mouse. $\boldsymbol{K}$, Image analysis of the percentage area covered by MAP2 immunoreactivity in the frontal cortex and hippocampus of nontg and hAPP tg mice treated with either saline or lithium. ${ }^{*} p<0.05$ compared with nontg controls by one-way ANOVA with post hoc Dunnett's test; $n=6$ mice per group. $L$, Image analysis of the percentage area covered by $A \beta$-immunoreactive plaques in the frontal cortex and hippocampus of nontg and hAPP tg mice treated with either saline or lithium. $M$, Image analysis of the levels of tau-p immunoreactivity in the frontal cortex and hippocampus of nontg and hAPP tg mice treated with either saline or lithium. ${ }^{*} p<0.05$ compared with saline-treated hAPP $\operatorname{tg}$ mice by one-way ANOVA with post hoc Tukey-Kramer test; $n=6$ mice per group. Scale bars: $\boldsymbol{B}-\boldsymbol{D}, \boldsymbol{H}-\boldsymbol{J}, 20 \mu \mathrm{m} ; \boldsymbol{E}-\mathbf{G}, 100 \mu \mathrm{m}$. 
ylated tau: AT8 (mouse monoclonal, 1:1000; Innogenetics, Alpharetta, GA), PHF-1 (mouse monoclonal, 1:1000; generously provided by Dr. Peter Davies), and CP13 (mouse monoclonal, 1:1000; generously provided by Dr. Peter Davies). After overnight incubation with primary antibodies, membranes were incubated with secondary antibodies tagged with HRP (1:5000; Santa Cruz Biotechnology) and visualized by enhanced chemiluminescence and analyzed with a Versadoc XL imaging apparatus (Bio-Rad). Analysis of actin levels was used as a loading control.

For determination of GSK $3 \beta$ activity, briefly as described previously (Hashimoto et al., 2002), brain homogenate supernatants from DNGSK $3 \beta$ tg and nontg mice were preadsorbed with a protein G-Sepharose (Amersham Biosciences, Uppsala, Sweden) for $1 \mathrm{~h}$, and the precleared lysates were immunoprecipitated (IP) with anti-GSK3 $\beta$ monoclonal antibody (1:50; Santa Cruz Biotechnology) overnight at $4^{\circ} \mathrm{C}$, followed by incubation with protein $\mathrm{G}$-Sepharose for $2 \mathrm{~h}$ at $4^{\circ} \mathrm{C}$. The immune complexes were then washed with lysis buffer and with kinase buffer. Finally, the immune complexes were incubated in kinase buffer containing phosphoglycogen synthase-2 peptides or the Ala21 mutant peptides (Upstate Biotechnology, Lake Placid NY) and $10 \mu \mathrm{Ci}$ of $\left[\gamma^{-}{ }^{32} \mathrm{P}\right]$ ATP $(6000 \mathrm{Ci} /$ mmol; PerkinElmer, Boston, MA). Reactions were terminated by the addition of $5 \mu \mathrm{l}$ of $500 \mathrm{~mm}$ EDTA and $5 \mathrm{~mm}$ ATP. Samples were then spotted onto Whatman (Maidstone, UK) P81 phosphocellulose filter paper. The filters were washed with $180 \mathrm{~mm}$ phosphoric acid, dried with acetone, and analyzed by scintillation counting. To confirm that GSK3 $\beta$ activity could be restored by dephosphorylation in the DN-GSK3 $\beta$ tg mice, brain homogenates were immunoprecipitated as described above with an antibody against GSK3 $\beta$. The IP samples were then treated with $100 \mathrm{mU} / \mathrm{ml} \mathrm{PP} 1 \gamma$ (Calbiochem), which specifically dephosphorylates GSK $3 \beta$, for $30 \mathrm{~min}$ at $30^{\circ} \mathrm{C}$ essentially as described previously (McManus et al., 2005). The dephosphorylation reaction was terminated by the addition of $100 \mu \mathrm{M}$ microcystin-LR (Calbiochem), an inhibitor of PP1 $\gamma$. Control experiments included immunoprecipitation with a nonimmune IgG and treatment with vehicle alone or PP1 $\gamma$ inactivated by preincubation with microcystin-LR for $30 \mathrm{~min}$ at $30^{\circ} \mathrm{C}$. After these treatments, the samples were assayed for GSK3 $\beta$ activity as described above or subjected to immunoblot analysis with an antibody against GSK3 $\beta$ phosphorylated at Ser9.

Evaluation of neurodegenerative alterations. To analyze the integrity of the dendritic arbor, briefly as described previously (Rockenstein et al., 2005b), blind-coded 40- $\mu \mathrm{m}$-thick vibratome sections from mouse brains fixed in $4 \%$ paraformaldehyde were immunolabeled with the mouse monoclonal antibody against microtubule-associated protein-2 (MAP2) (dendritic marker, 1:40; Chemicon), as described previously (Mucke et al., 1995). After overnight incubation with the primary antibodies, sections were incubated with fluorescein isothiocyanate (FITC)-conjugated horse anti-mouse IgG secondary antibody ( 1 :75; Vector Laboratories, Burlingame, CA), transferred to SuperFrost slides (Fisher Scientific, Tustin, CA), and mounted under glass coverslips with anti-fading media (Vector Laboratories). All sections were processed under the same standardized conditions. The immunolabeled blind-coded sections were imaged with the laser scanning confocal microscope (LSCM) (MRC1024; Bio-Rad) and analyzed with the NIH Image 1.43 program, as described previously (Toggas et al., 1994; Mucke et al., 1995). For each mouse, the frontal cortex and hippocampus were analyzed in a total of three sections, and, for each section, an average of 10 fields were examined.

Analysis of AD-like neuropathology. To eval- uate the effects of GSK3 $\beta$ inhibition on amyloid plaque load and tau phosphorylation, briefly as described previously (Rockenstein et al., 2002a), vibratome sections were incubated overnight at $4^{\circ} \mathrm{C}$ with the mouse monoclonal antibody 6E10 (1:1000; Signet Laboratories), which specifically recognizes $\mathrm{A} \beta$ and the AT8 antibody that recognizes phosphorylated tau (tau-p) (Ser202; Pierce, Rockford, IL), followed by FITCconjugated anti-mouse IgG (Vector Laboratories). The FITC-labeled sections were imaged with the LSCM as described previously (Mucke et al., 2000). Digitized images were analyzed with the NIH Image 1.43 program to determine the percentage area of the neuropil occupied by $\mathrm{A} \beta$ immunoreactive deposits in the frontal cortex and hippocampus and the levels of AT8 immunoreactivity (pixel intensity). Three immunolabeled sections (an average of 10 fields per sections) were analyzed per mouse, and the average of individual measurements was used to calculate group means.

Statistical analysis. Analyses were performed with the StatView 5.0 program (SAS Institute, Cary, NC). Differences among means were assessed by one-way ANOVA with post hoc Dunnett's test. Comparisons between two groups were done with the two-tailed unpaired Student's $t$ test. Correlation studies were performed by simple regression analysis, and the null hypothesis was rejected at the 0.05 level.

\section{Results}

Lithium chloride treatment reduces the performance deficits and neuropathological alterations in hAPP tg mice

To test the potential neuroprotective effects of lithium in a tg model of AD-like pathology, mice were treated with lithium chloride $(n=6)$ at a dose of $20 \mathrm{mg} / \mathrm{kg}$ intraperitoneally or saline alone $(n=6)$ starting at 3 months of age for 3 months and tested (at 6 months of age) in the water maze. By the end of the study, lithium chloride plasma levels were in the range of $0.1-0.2 \mathrm{mEq} / \mathrm{L}$. Compared with saline-treated nontg control mice, saline-treated
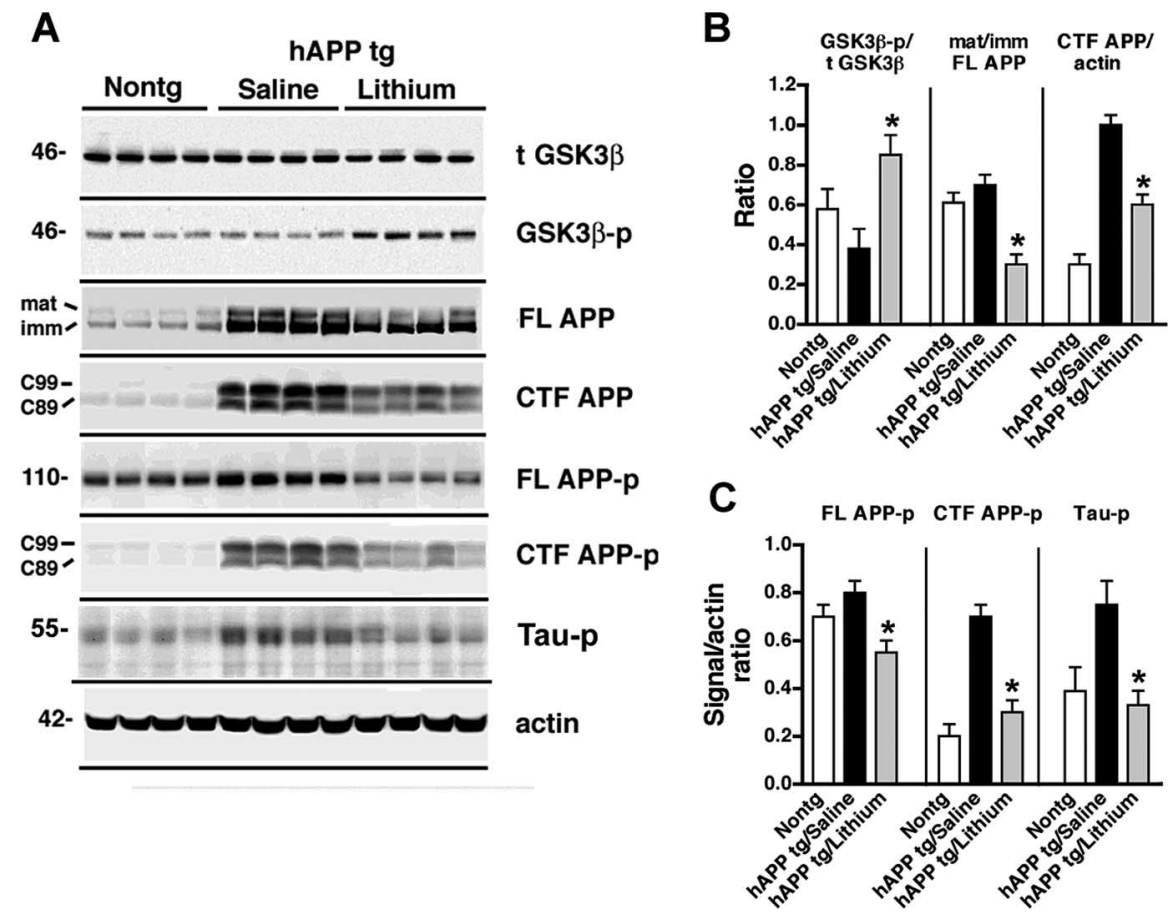

Figure 2. Immunoblot analysis of the effects of lithium on GSK3 $\beta$, APP maturation, and tau phosphorylation in hAPP $\operatorname{tg}$ mice. $\boldsymbol{A}$, Representative Western blots demonstrating the patterns of immunoreactivity of total t-GSK3 $\beta, G S K 3 \beta-p$, mature (mat) and immature (imm) forms of FL APP, CTFs (C99 and (89) of APP, FL APP-p, CTF APP-p, and tau-p in homogenates from the frontal cortex of 6-month-old nontg or hAPP tg mice treated with either saline or lithium. $\boldsymbol{B}$, Image analysis of the levels of GSK3 $\beta$-p, the ratio of mature/immature FL APP, and levels of APP CTFs (mean of 99 and (89) in the frontal cortex of nontg and hAPP tg mice treated with saline or lithium. C, Image analysis of the levels of FL APP-p, CTF APP-p (mean of (99 and (89), and tau-p in the frontal cortex of nontg and hAPP $\operatorname{tg}$ mice treated with saline or lithium. ${ }^{*} p<0.05$ compared with saline-treated hAPP tg mice by unpaired two-tailed Student's $t$ test; $n=6$ mice per group. 
hAPP tg mice showed significant performance deficits in the water maze (Fig. 1A) (supplemental Fig. 1A,B, available at www. jneurosci.org as supplemental material). These alterations were not related to motor impairments but rather to spatial learning deficits, because, on the final day of testing, when the platform was made visible there was no difference in the swim distances between the groups (Fig. $1 A$ ). Compared with the saline-treated group, lithium treatment ameliorated the performance deficits in the hAPP tg mice during the testing period with the invisible platform (Fig. 1A). No significant differences were observed between the saline- and lithium-treated hAPP tg mice in the probe test (supplemental Fig. $1 A, B$, available at www.jneurosci.org as supplemental material). Control studies in a group of nontg mice showed no significant differences between saline and lithium treatment (supplemental Fig. $2 A, B$, available at www.jneurosci. org as supplemental material).

Consistent with the water maze findings (Fig. $1 A$ ), compared with nontg controls (Fig. $1 B$ ), in the saline-treated hAPP tg group there was a significant reduction in the density of MAP2immunoreactive dendrites in the frontal cortex (Fig. $1 C, K$ ), and hippocampus (Fig. $1 K$ ). In contrast, in the lithium-treated hAPP tg group (Fig. $1 D, K$ ), the percentage area of the neuropil occupied by MAP2-immunoreactive dendrites was comparable with the nontg age-matched control group. Because inactivation of GSK $3 \beta$ by lithium has been proposed as one of the mechanisms by which lithium protects the CNS from injury (Li et al., 2002), homogenates from the brains of mice treated with lithium or saline were prepared, and levels of GSK3 $\beta$-p (Ser9) were determined. Western blot analysis showed that, although levels of t-GSK $3 \beta$ were unchanged among groups, in the brains of the mice receiving lithium, there was an increase in the GSK $3 \beta-p$ signal compared with the saline-treated control group (Fig. $2 A, B)$. Consistent with these findings, the immunoprecipitation assay showed that levels of GSK3 $\beta$ activity were decreased in the lithium-treated hAPP tg mice compared with saline-treated controls (Fig. 3A).

To further investigate the mechanisms through which GSK3 $\beta$ inactivation might be neuroprotective in hAPP tg mice, the levels of APP and its metabolites were analyzed. By ELISA, A $\beta_{1-42}$ levels were significantly reduced in the lithium-treated hAPP tg mice compared with saline control group (Fig. $3 B$ ). Consistent with this, the neuropathological analysis with an antibody against $\mathrm{A} \beta$ (Fig. $1 E-G, L$ ) showed that, compared with the saline-treated group (Fig. $1 F, L)$, lithium treatment reduced the percentage area of the neuropil covered by $\mathrm{A} \beta$-immunoreactive plaques in the hAPP tg mice (Fig. 1G,L). Immunoblot analysis showed that the ratio of mature to immature FL-APP was altered in the lithiumtreated mice compared with the saline-treated group (Fig. $2 A, B$ ) rather than the levels of total FL-APP. In addition, lithium treatment was associated with a decrease in levels of CTFs of APP (Fig. $2 A, B)$. To confirm the effects of lithium on GSK $3 \beta$ by an independent and previously validated approach (Phiel et al., 2003; Noble et al., 2005), levels of tau-p (a GSK3 $\beta$ target) were analyzed (Fig. $1 H-J, M)$. Immunocytochemical studies showed that, compared with the nontg control (Fig. $1 H$ ), saline-treated hAPP tg mice displayed increased neuronal levels of tau-p immunoreactivity (Fig. 1I) that were reduced by lithium treatment (Fig. $1 J, M)$. This effect of lithium on hAPP tg mice was confirmed by immunoblot (Fig. $2 A, C$ ). These results suggest that either lithium decreases $A \beta$ levels by reducing APP maturation or by increasing A $\beta$ degradation. Because APP maturation, subcellular distribution, and transport to the axonal terminal in which proteolysis and generation of $\mathrm{A} \beta$ occurs is phosphorylation depen-
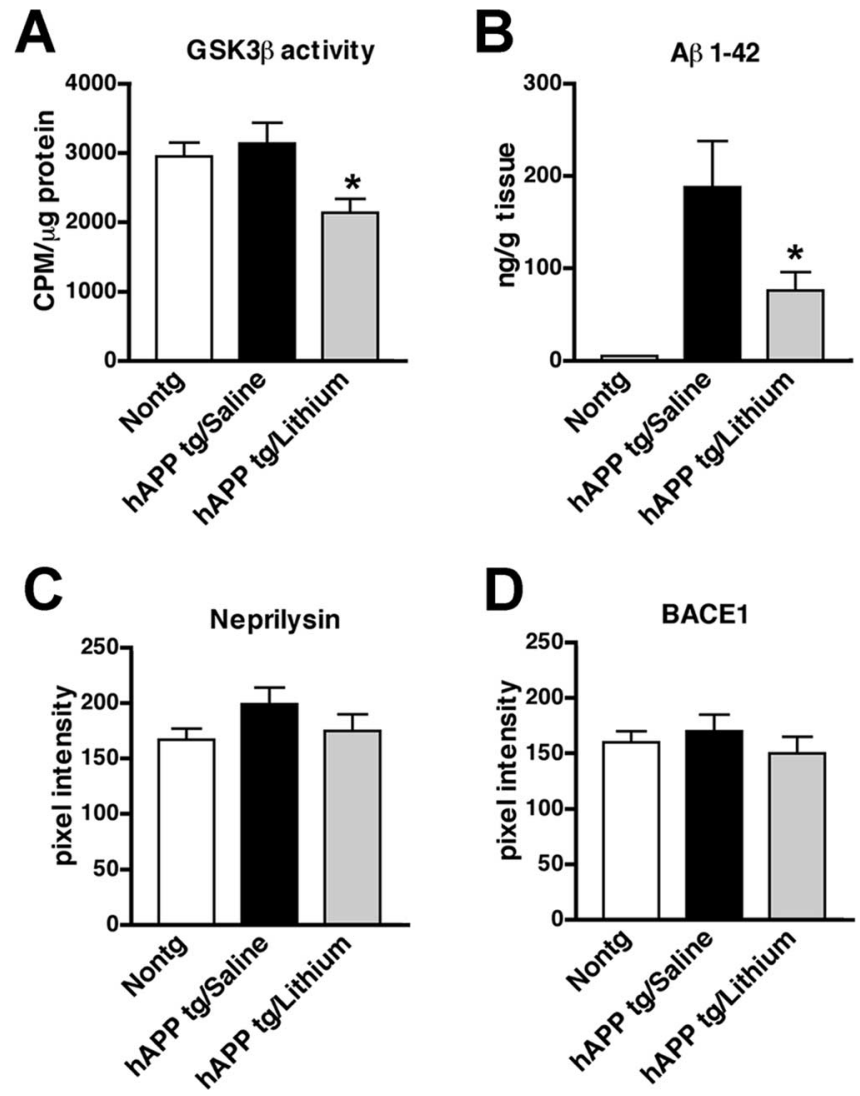

Figure 3. Effects of lithium on GSK3 $\beta$ activity and APP metabolism in hAPP tg mice. $A$, Levels of GSK3 $\beta$ activity, expressed as counts per minute (CPM) per microgram of protein, in homogenates from the frontal cortex of nontg and hAPP tg mice treated with saline or lithium. $\boldsymbol{B}$, $A \beta_{1-42}$ levels in homogenates from the frontal cortex of nontg and hAPP tg mice treated with saline or lithium. $C$, Immunoreactivity levels of the $A \beta$-cleaving enzyme neprilysin in homogenates from the frontal cortex of nontg and hAPP $\mathrm{tg}$ mice treated with saline or lithium. $\boldsymbol{D}$, Levels of BACE1 immunoreactivity in homogenates from the frontal cortex of nontg and hAPP tg mice treated with saline or lithium. ${ }^{*} p<0.05$ compared with saline-treated hAPP tg mice by one-way ANOVA with post hoc Tukey-Kramer test; $n=6$ mice per group.

dent (Koo et al., 1990; Ando et al., 1999; Iijima et al., 2000; da Cruz e Silva and da Cruz e Silva, 2003; Lee et al., 2003) and GSK3 $\beta$ [as well as stress-activated protein kinase (SAPK) and cyclindependent kinase-5 (CDK5)] plays a role in this process (Aplin et al., 1996; Iijima et al., 2000; Ryder et al., 2003), immunoblot analysis was performed with an antibody against APP-p (Thr668). This study showed that, in hAPP tg mice treated with lithium, there was a reduction in the phosphorylation of FL and CTFs of APP compared with the saline-treated hAPP tg animals (Fig. 2A,C). In nontg mice, levels of total endogenous FL-APP were not affected by lithium treatment, but levels of APP-p were decreased, supporting the notion that the effects of lithium on APP are mediated by GSK $3 \beta$ and APP maturation rather than through a specific effect of GSK3 $\beta$ on the Thyl promoter (supplemental Fig. $2 C, D$, available at www.jneurosci.org as supplemental material). Levels of the $\mathrm{A} \beta$-degrading enzyme neprilysin and BACE1 were not different between the saline- and lithiumtreated hAPP tg mice (Fig. $3 C, D$ ). Together, these results suggest that lithium treatment contributes to the decreased $\mathrm{A} \beta$ production by reducing phosphorylation-dependent maturation of APP. 


\section{Overexpression of DN-GSK3 $\beta$ in tg mice reduces the performance deficits and neuropathological alterations in hAPP tg mice}

To verify by an independent approach that blocking the GSK3 $\beta$ pathway prevents the behavioral and pathological alterations in the hAPP tg mice, a DN-GSK3 $\beta$ tg was generated and crossed with the hAPP tg mice. In this model, overexpression of GSK $3 \beta$ results in Akt activation, which in turn phosphorylates (and inactivates) GSK $3 \beta$. Although these mice overexpress $\operatorname{tGSK} 3 \beta$, the net effect was a decrease in activity. Two lines of the DN-GSK3 $\beta$ were obtained. Analysis of mRNA (Fig. $4 A, B$ ) and GSK3 $\beta$ (Fig. $4 C-E$ ) immunoreactivity showed that line 22 was the highest expresser. Therefore, line 22 was selected for additional studies and crosses with the hAPP tg mice. Immunoblot analysis showed that levels of $\mathrm{t}-\mathrm{GSK} 3 \beta$ in the DNGSK $3 \beta$ tg mice and hAPP/DN-GSK3 $\beta$ double tg mice were higher compared with single hAPP tg mice and nontg controls (Fig. $5 A, B$ ), but most of the GSK3 $\beta$ in the tg mice was phosphorylated at Ser9 (Fig. $5 A, B$ ), rendering both the endogenous as well as the transgenic GSK $3 \beta$ inactive. Consistent with the GSK3 $\beta$-p immunoblot analysis showing increased levels of inactive phosphorylated GSK $3 \beta$, kinase activity assay by immunoprecipitation showed that, compared with nontg and hAPP tg mice, in the DN-GSK3 $\beta$ tg and hAPP/DN-GSK3 $\beta$ double tg mice, GSK3 $\beta$ activity was significantly decreased (Fig. $6 A$ ). This reduction resulted from the increased phosphorylation of GSK $3 \beta$ because kinase activity was restored in immunoprecipitates from DN-GSK $3 \beta$ tg mice after treatment with PP1 $\gamma$ (Fig. $6 B)$. Consistent with the kinase activity assay, immunoblot analysis showed that treatment with $\mathrm{PP} 1 \gamma$ resulted in decreased GSK3 $\beta$ phosphorylation at Ser9 (Fig. 6C). To begin to understand how overexpression of GSK3 $\beta$ in this system results in decreased GSK $3 \beta$ activity levels, an upstream and a downstream regulator and GSK3 $\beta$ phosphorylation were analyzed. Immunoblot analysis showed that Akt phosphorylation was increased, whereas levels of PP1 were unchanged (Fig. 5A,B). This suggests that the dominant-negative effects in these $\operatorname{tg}$ mice are mediated by a feedback loop in which Akt is activated and this, in turn, inactivates GSK3 $\beta$.

At 6 months of age, mice were tested in the water maze. Consistent with previous studies (Rockenstein et al., 2003), at this age, hAPP tg mice displayed performance deficits in the spatial learning part of the test (Fig. $7 A$ ). In contrast, DN-GSK3 $\beta$ tg mice as well as hAPP/DN-GSK3 $\beta$ double tg mice performed similarly to nontg littermates (Fig. 7A). No significant effects were observed in the probe component of the trial (supplemental Fig. 1C,D, available at www.jneurosci.org as supplemental material). Neuropathological analysis showed that, compared with hAPP tg mice, the DN-GSK3 $\beta$ tg mice and the hAPP/DN-GSK3 $\beta$ double tg mice displayed preservation of the dendritic structure and increased levels of MAP2 immunoreactivity mice (Fig. $7 B-E, N$ ). Additional studies of AD-like neuropathology included immunocytochemical analysis of amyloid plaque load using the $6 \mathrm{E} 10$ (line $39 ; \boldsymbol{E}$ ). Scale bar, $90 \mu \mathrm{m}$
B
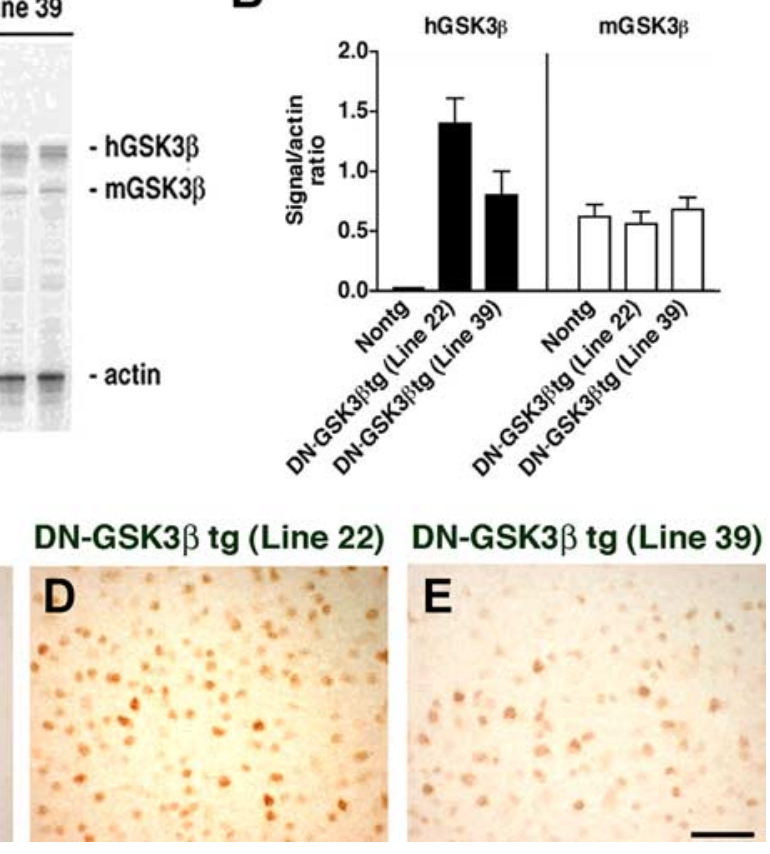

Figure 4. Generation and characterization of DN-GSK3 $\beta$ tg mice. Analysis of mRNA levels in nontg and DN-GSK3 $\beta$ tg mice. Samples were analyzed using RPA. $\boldsymbol{A}$, Representative autoradiograph showing mRNA levels of human (h)GSK3 $\beta$, murine

antibody. Computer-aided analysis showed that, whereas the hAPP tg mice displayed high levels of amyloid load, in the hAPP/ DN-GSK3 $\beta$ double tg mice, only a few amyloid deposits were identified and the amyloid levels were reduced (Fig. $7 F-I, O$ ). Moreover, the reduced activity of GSK $3 \beta$ was associated with decreased levels of neuronal tau-p immunoreactivity (Fig. 7J$M, P)$. Immunoblot analysis with PHF-1, CP13, and AT8 confirmed that the DN-GSK3 $\beta$ resulted in decreased levels of tau-p (Fig. 5C,E). Consistent with the immunocytochemical analysis, ELISA showed that levels of $\mathrm{A} \beta$ were lower in the hAPP/DNGSK3 $\beta$ double tg mice compared with the hAPP tg mice (Fig. $6 D)$. Western blot analysis showed that, compared with the hAPP tg mice, the ratio of mature to immature FL-APP (Fig. 5C,D) and levels of phosphorylated (Thr668) FL and CTFs C99 and C89 of APP (Fig. 5C,D) were reduced in the hAPP/DN-GSK3 $\beta$ double tg mice. In contrast, levels of neprilysin and BACE1 were unchanged between hAPP/DN-GSK3 $\beta$ double tg mice compared with the hAPP tg (Fig. 6E,F). Together, these results support the possibility that inactivation of the GSK $3 \beta$ pathway might also reduce $\mathrm{A} \beta$ levels by regulating APP phosphorylation rather than expression or degradation.

\section{Discussion}

Previous studies have shown that short-term lithium treatment decreases amyloid production and tau phosphorylation in tg mice (Perez et al., 2003; Phiel et al., 2003; Noble et al., 2005). In the present study, we treated hAPP tg mice for a longer term with lithium or expressed a DN-GSK3 $\beta$ and demonstrate the following new findings: (1) that GSK3 $\beta$ inactivation results in neuroprotection and improved behavioral performance in the water maze, and (2) that reduced activity of this kinase might also ameliorate $\mathrm{AD}$-like neuropathology because of the decreased phos- 

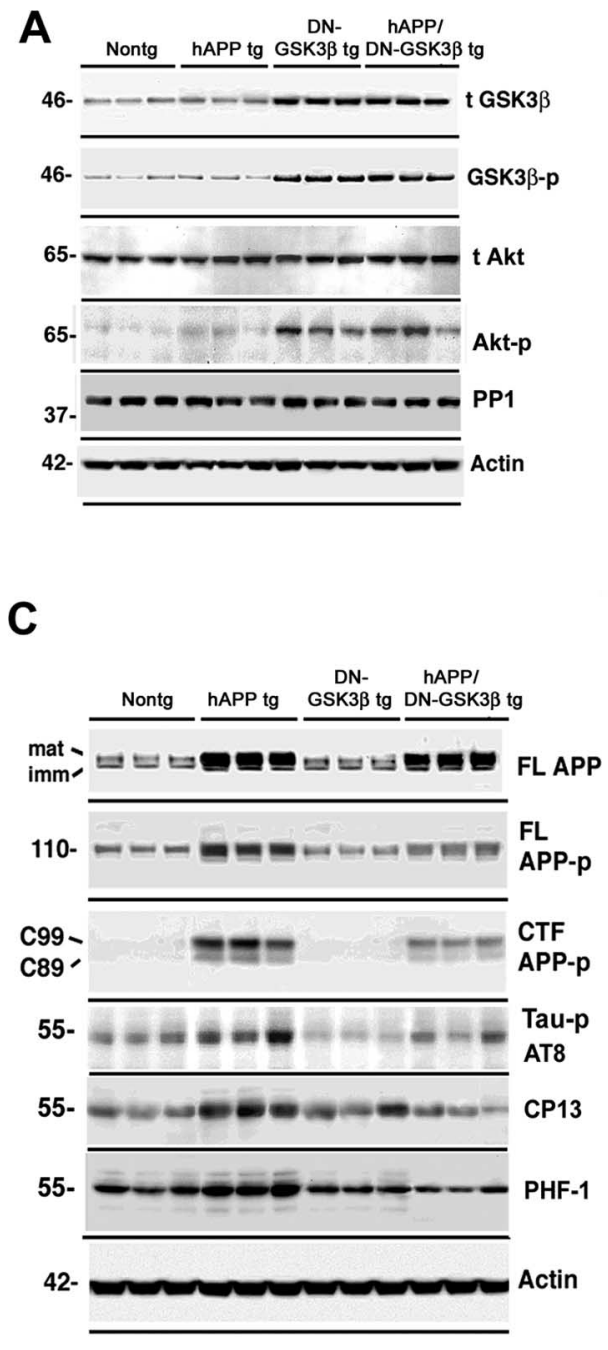

behavioral deficits (Hernandez et al., 2002), in our model the overexpressed GSK $3 \beta$ resulted in a dominant-negative effect in which most of this kinase was phosphorylated at Ser9 by Akt, therefore rendering GSK $3 \beta$ inactive. This overall reduction in the activity of GSK $3 \beta$ was associated with an amelioration of the AD-like neuropathology and behavioral deficits in the water maze of hAPP tg mice. Furthermore, and in agreement with previous studies (Phiel et al., 2003; Su et al., 2004; Noble et al., 2005), we found that blocking the GSK3 $\beta$ pathway in hAPP tg mice resulted in reduced $A \beta$ production and amyloid plaque load, suggesting that the neuroprotective effects might be associated with decreased $A \beta$ levels. The neuroprotective effects of decreasing GSK3 $\beta$ activity in the hAPP tg mice were associated with improved performance in the water maze. This is consistent with recent studies that have shown that turning off GSK3 $\beta$ overexpression under the regulatory control of a conditional promoter reverses the spatial learning deficits (Hernandez et al., 2002; Engel et al., 2006). Because neurodegeneration and behavioral deficits in the hAPP tg model precede the phase of accelerated amyloid plaque deposition (Rockenstein et al., 2001), it is most likely that the protective effects were related to reduced levels of soluble $A \beta$ and formation of toxic oligomers rather than to the decreased plaque load. The mechanisms through which blocking GSK $3 \beta$ might result in reduced $A \beta$ production are a subject of investigation. For example, previous studies have shown that GSK3 $\beta$ interacts with presenilin and that inactivating GSK3 $\beta$ might result in decreased $\gamma$-secretase activity (Takashima et al., 1998; Baki et al., 2004; Su et al., 2004). Other mechanisms might also be involved; in this regard, the present study showed that blocking GSK3 $\beta$ resulted in decreased APP phosphorylation and maturation, a process necessary for $\mathrm{A} \beta$ generation (da Cruz e Silva and da Cruz e Silva, 2003; Lee et al., 2003; Rockenstein et al., 2005a). These results support the notion that, via regulation of phosphorylation,

phorylation of APP. Consistent with these findings, previous in vivo studies have shown that lithium protects the CNS against excitotoxicity (Nonaka et al., 1998; Elyaman et al., 2002), ischemia (Nonaka and Chuang, 1998; Bhat et al., 2000), dennervation (Manji et al., 1999), quinolinic acid (Wei et al., 2001), aluminum (Ghribi et al., 2002), and human immunodeficiency virus-gp120 (Everall et al., 2002).

Although previous GSK3 $\beta$ tg animal models have been designed to overexpress the constitutively active kinase, which results in neurodegeneration, tau hyperphosphorylation (Brownlees et al., 1997; Spittaels et al., 1999; Lucas et al., 2001), and blockage of GSK3 $\beta$ might retain APP in the early secretory pathway, depleting mature APP-p before it is transported to the axon terminals, in which a large proportion of $\mathrm{A} \beta$ generation by the $\gamma$-secretase complex takes place (Lee et al., 2005). This alteration of the subcellular distribution of APP might localize it to a compartment in which it might be less prone to be cleaved via the $\beta$-secretory pathway. In this context, the reduction of APP phosphorylation by inactivating GSK3 $\beta$ might result in a depletion of mature APP-p in the trans-Golgi compartment and a lesser amount of APP targeted to the distal axon, which would preclude $\mathrm{A} \beta$ generation at synaptic sites. 
The neuroprotective effects of lithium in the hAPP tg mice might not be exclusively related to the effects of this compound on the GSK3 $\beta$ signaling cascade but might involve the regulation of other kinases involved in neurodegeneration such as CDK5 and SAPK (Iijima et al., 2000; Ryder et al., 2003). Moreover, lithium has been shown to regulate the expression of oncogenes such as BclII, p53, and $\mathrm{Bax}$ (Bcl-2-associated $\mathrm{X}$ protein) (Chen and Chuang, 1999) to inhibit protein phosphatase A2 (Mora et al., 2002), to regulate the c-Jun $\mathrm{NH}$-terminal kinase pathway (Yuan et al., 1999), and to regulate the expression and function of transcription factors that bind to the activator protein-1 and cAMP response element sites, which play an important role in regulating cell survival (Ozaki and Chuang, 1997; Yuan et al., 1999). Furthermore, at therapeutically relevant doses, lithium regulates inositol metabolism (O'Donnell et al., 2000; Williams et al., 2002) and activates the phosphoinositol-3 kinase (PI3K)-Akt signaling pathway (ChaleckaFranaszek and Chuang, 1999; Mora et al., 1999) that is known to inhibit GSK3 $\beta$, thereby promoting cell survival (Cross et al., 1995; Shaw and Cohen, 1999; Hashimoto et al., 2002). Supporting a role of GSK3 $\beta$ inactivation in lithium-mediated neuroprotection, lithium directly inhibits GSK3 $\beta$ by competition for magnesium (Ryves and Harwood, 2001), and it directly binds GSK3 $\beta$ in staurosporinetreated cells, thereby protecting through inhibition of GSK3 $\beta$ (Bijur et al., 2000). The role of lithium in GSK3 $\beta$ signaling is particularly important for understanding its neurotrophic activity because GSK $3 \beta$ is key in regulating CNS development (Joutel and Tournier-Lasserve, 1998; Dierick and Bejsovec, 1999) and cell fate (Pap and Cooper, 1998; Torres et al., 1999). This observation is also consistent with previous studies showing that trophic factors such as fibroblast growth factor-1 promote GSK3 $\beta$ inactivation via Akt-mediated phosphorylation at Ser9 (Sutherland et al., 1993; Hashimoto et al., 2002), thereby facilitating $\beta$-catenin nuclear localization (Bienz, 1999) and cell survival (Hashimoto et al., 2002). Inactivation of GSK3 $\beta$ correlates with cell survival, whereas activation of GSK $3 \beta$ can result in cell death (Pap and Cooper, 1998). The mechanisms through which lithium regulates GSK $3 \beta$ activity are not completely clear, but recent studies support the possibility that lithium regulates the PI3KAkt pathway (Klein and Melton, 1996; Chalecka-Franaszek and Chuang, 1999; Mora et al., 1999; Takahashi et al., 1999; Bhat et al., 2000; Elyaman et al., 2002; Mai et al., 2002), which is directly upstream of GSK3 $\beta$ (Cross et al., 1995).

Alternatively, it is possible that blocking GSK $3 \beta$ might be protective in hAPP tg mice by regulating or decreasing the phosphorylation of other substrates. Among them, considerable attention has been dedicated to the role of GSK3 $\beta$ on tau phosphorylation and the formation of tangles (Mandelkow et al., 1992; Baum et al., 1996; Pei et al., 1999; Ishizawa et al., 2003). Interestingly, recent studies have shown that lithium treatment reduces tau hyper-
B
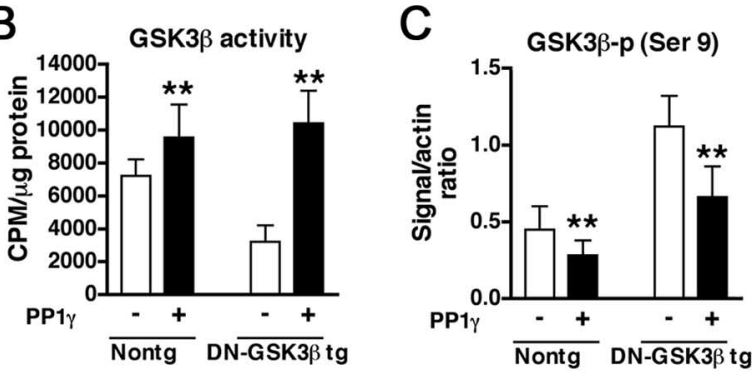

E
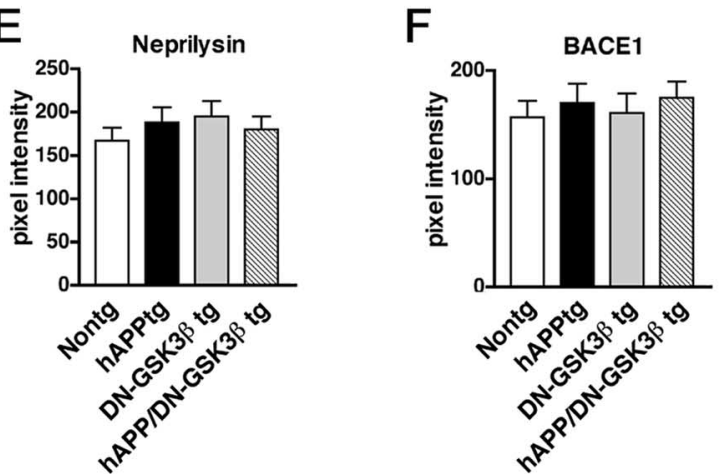

Figure 6. GSK3 $\beta$ activity and APP metabolism in hAPP/DN-GSK3 $\beta$ double tg mice. $\boldsymbol{A}$, Levels of GSK3 $\beta$ activity in immunoitated samples from the frontal cortex of nontg, hAPP $\operatorname{tg}, \mathrm{DN}-\mathrm{GSK} 3 \beta \mathrm{tg}$, and hAPP/DN-GSK3 $\beta$ double $\mathrm{tg}$ mice. $\boldsymbol{B}$, Levels of

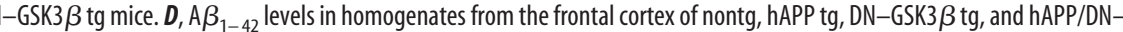
two-tailed Student's $t$ test; $n=6$ mice per group. ${ }^{* *} p<0.05$ compared with samples that were not treated with PP1 $\gamma$ by unpaired two-tailed Student's $t$ test; $n=6$ mice per group.

phosphorylation and formation of tangle-like lesions in tau tg mice (Perez et al., 2003; Phiel et al., 2003; Nakashima et al., 2005; Noble et al., 2005).

In conclusion, the present study showed that inhibition of the GSK3 $\beta$ pathway with lithium or by genetic manipulation not only reduces $\mathrm{A} \beta$ production, but it also results in neuroprotection and improved water maze performance in the hAPP tg mice. These effects were associated with reduced phosphorylation of APP and generation of neurotoxic metabolites of APP. Our study further supports the therapeutic rationale of using GSK3 $\beta$ blockers in the treatment of AD.

\section{References}

Anderton BH, Betts J, Blackstock WP, Brion JP, Chapman S, Connell J, Dayanandan R, Gallo JM, Gibb G, Hanger DP, Hutton M, Kardalinou E, Leroy K, Lovestone S, Mack T, Reynolds CH, Van Slegtenhorst M (2001) Sites of phosphorylation in tau and factors affecting their regulation. Biochem Soc Symp 73-80.

Ando K, Oishi M, Takeda S, Iijima K, Isohara T, Nairn AC, Kirino Y, Greengard P, Suzuki T (1999) Role of phosphorylation of Alzheimer's amyloid precursor protein during neuronal differentiation. J Neurosci 19:4421-4427.

Aplin AE, Gibb GM, Jacobsen JS, Gallo JM, Anderton BH (1996) In vitro phosphorylation of the cytoplasmic domain of the amyloid precursor protein by glycogen synthase kinase-3beta. J Neurochem 67:699-707.

Baki L, Shioi J, Wen P, Shao Z, Schwarzman A, Gama-Sosa M, Neve R, Robakis NK (2004) PS1 activates PI3K thus inhibiting GSK-3 activity and tau overphosphorylation: effects of FAD mutations. EMBO J 23:2586-2596.

Baum L, Hansen L, Masliah E, Saitoh T (1996) Glycogen synthase kinase 3 

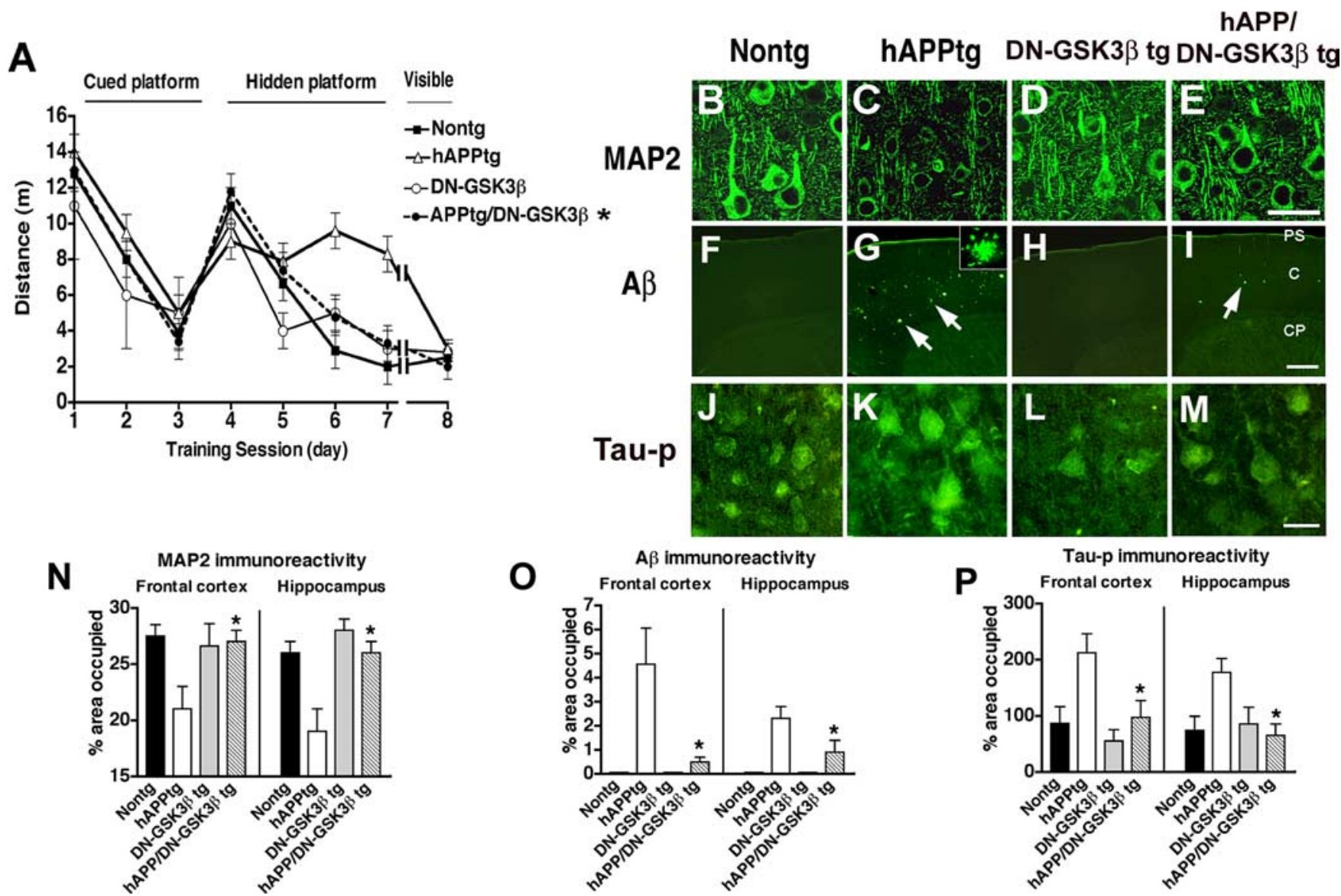

Figure 7. Behavioral performance in the water maze and neuropathological analysis of dendritic structure and amyloid deposition in hAPP/DN-GSK3 $\beta$ double tg mice. $A$, During the hidden platform portion of the water maze test, $h$ APP tg mice showed performance deficits compared with nontg and DN-GSK3 $\beta \operatorname{tg}$ mice that were ameliorated in the hAPP/DN-GSK3 $\beta \operatorname{tg}$ mice. $B$, Laser scanning confocal microscopic image of MAP2 immunoreactivity in the frontal cortex of a nontg mouse. C, Decreased MAP2 immunoreactivity in the frontal cortex of an hAPP tg mouse. D, MAP2 immunoreactivity in the frontal cortex of a DN-GSK3 $\beta$ tg mouse. $E$, Restored MAP2 immunoreactivity in the frontal cortex of an hAPP/DN-GSK3 $\beta$ tg mouse. $F$, Low-power laser scanning confocal microscopic image of the frontal cortex of a nontg mouse immunostained with an antibody against $A \beta(6 E 10) . G$, Increased amyloid deposition and plaques (arrows) in the frontal cortex of an hAPP $\operatorname{tg}$ mouse. Higher-power inset shows the morphology of an individual A $\beta$-immunoreactive plaque. $\boldsymbol{H}$, Background levels of A $\beta$ immunoreactivity in the frontal cortex of a DN-GSK3 $\beta$ tg mouse. $\boldsymbol{I}$, Reduced $A \beta$ immunoreactivity in the frontal cortex of an hAPP/DN-GSK3 $\beta$ tg mouse immunostained with an antibody against A $\beta$. PS, Pial surface; $C$, cortex; $C P$, caudoputamen. J, Laser scanning confocal microscopic image of tau-p (AT8) immunoreactivity in the frontal cortex of a nontg mouse. $\boldsymbol{K}$, Increased tau-p immunoreactivity in the frontal cortex of an hAPP tg mouse. $\boldsymbol{L}$, tau-p immunoreactivity in the frontal cortex of a DN-GSK3 $\beta$ tg mouse. $M$, Reduced tau-p immunoreactivity in the frontal cortex of an hAPP/DN-GSK3 $\beta \operatorname{tg}$ mouse. $N$, Image analysis of the percentage area covered by MAP2 immunoreactivity in the frontal cortex and hippocampus of nontg, hAPP tg, DN-GSK3 $\beta$ tg, and hAPP/DN-GSK3 $\beta \operatorname{tg}$ mice. 0 , Image analysis of the percentage area covered by $A \beta$-immunoreactive plaques in the frontal cortex and hippocampus of nontg, hAPP tg, DN-GSK3 $\beta$ tg, and hAPP/DN-GSK3 $\beta \operatorname{tg}$ mice. $P$, Image analysis of the percentage area covered by tau-p immunoreactivity in the frontal cortex and hippocampus of nontg, $\mathrm{hAPP} \operatorname{tg}, \mathrm{DN}-\mathrm{GSK} 3 \beta \mathrm{tg}$, and hAPP/DN-GSK3 $\beta \operatorname{tg}$ mice. ${ }^{*} p<0.05$ compared with hAPP tg mice by one-way ANOVA with post hoc Tukey-Kramer; $n=6$ mice per group. Scale bars: $\boldsymbol{B}-\boldsymbol{E}, \mathbf{J}-\boldsymbol{M}, 20 \mu \mathrm{m} ; \boldsymbol{F}-\boldsymbol{I}, 100 \mu \mathrm{m}$.

alteration in Alzheimer disease is related to neurofibrillary tangle formation. Mol Chem Neuropathol 29:253-261.

Beach T, Walker R, McGeer E (1989) Patterns of gliosis in Alzheimer's disease and aging cerebrum. Glia 2:420-436.

Bhat RV, Shanley J, Correll MP, Fieles WE, Keith RA, Scott CW, Lee CM (2000) Regulation and localization of tyrosine216 phosphorylation of glycogen synthase kinase-3beta in cellular and animal models of neuronal degeneration. Proc Natl Acad Sci USA 97:11074-11079.

Bienz M (1999) APC: the plot thickens. Curr Opin Genet Dev 9:595-603.

Bijur GN, De Sarno P, Jope RS (2000) Glycogen synthase kinase-3beta facilitates staurosporine- and heat shock-induced apoptosis. Protection by lithium. J Biol Chem 275:7583-7590.

Brownlees J, Irving NG, Brion JP, Gibb BJ, Wagner U, Woodgett J, Miller CC (1997) Tau phosphorylation in transgenic mice expressing glycogen synthase kinase-3beta transgenes. NeuroReport 8:3251-3255.

Chalecka-Franaszek E, Chuang D (1999) Lithium activates the serine/threonine kinase Akt-1 and suppresses glutamate-induced inhibition of Akt-1 activity in neurons. Proc Natl Acad Sci USA 96:8745-8750.

Chen RW, Chuang DM (1999) Long term lithium treatment suppresses p53 and Bax expression but increases Bcl-2 expression. A prominent role in neuroprotection against excitotoxicity. J Biol Chem 274:6039-6042.
Cross D, Alessi D, Cohen P, Andjelkovich M, Hemmings B (1995) Inhibition of glycogen synthase kinase- 3 by insulin mediated by protein kinase B. Nature 378:785-789.

da Cruz e Silva EF, da Cruz e Silva OA (2003) Protein phosphorylation and APP metabolism. Neurochem Res 28:1553-1561.

DeKosky S, Scheff S (1990) Synapse loss in frontal cortex biopsies in Alzheimer's disease: correlation with cognitive severity. Ann Neurol 27:457-464.

DeKosky ST, Scheff SW, Styren SD (1996) Structural correlates of cognition in dementia: quantification and assessment of synapse change. Neurodegeneration 5:417-421.

Dierick H, Bejsovec A (1999) Cellular mechanisms of wingless/Wnt signal transduction. Curr Top Dev Biol 43:153-190.

Elyaman W, Terro F, Wong NS, Hugon J (2002) In vivo activation and nuclear translocation of phosphorylated glycogen synthase kinase-3beta in neuronal apoptosis: links to tau phosphorylation. Eur J Neurosci 15:651-660.

Engel T, Hernandez F, Avila J, Lucas JJ (2006) Full reversal of Alzheimer's disease-like phenotype in a mouse model with conditional overexpression of glycogen synthase kinase-3. J Neurosci 26:5083-5090.

Everall IP, Bell C, Mallory M, Langford D, Adame A, Rockestein E, Masliah E 
(2002) Lithium ameliorates HIV-gp120-mediated neurotoxicity. Mol Cell Neurosci 21:493-501.

Ghribi O, Herman MM, Spaulding NK, Savory J (2002) Lithium inhibits aluminum-induced apoptosis in rabbit hippocampus, by preventing cytochrome $\mathrm{c}$ translocation, Bcl-2 decrease, Bax elevation and caspase-3 activation. J Neurochem 82:137-145.

Harr SD, Hollister RD, Hyman BT (1996) Glycogen synthase kinase 3 alpha and 3 beta do not colocalize with neurofibrillary tangles. Neurobiol Aging 17:343-348.

Hashimoto M, Sagara Y, Everall IP, Mallory M, Everson A, Langford D, Masliah E (2002) Fibroblast growth factor 1 regulates signaling via the GSK3 $\beta$ pathway: implications for neuroprotection. J Biol Chem 277:32985-32991.

Hernandez F, Borrell J, Guaza C, Avila J, Lucas JJ (2002) Spatial learning deficit in transgenic mice that conditionally over-express GSK-3beta in the brain but do not form tau filaments. J Neurochem 83:1529-1533.

Hof P, Morrison J (1994) The cellular basis of cortical disconnection in Alzheimer disease and related dementing conditions. In: Alzheimer disease (Terry R, Katzman R, Bick K, eds), pp 197-230. New York: Raven.

Iijima K, Ando K, Takeda S, Satoh Y, Seki T, Itohara S, Greengard P, Kirino Y, Nairn AC, Suzuki T (2000) Neuron-specific phosphorylation of Alzheimer's beta-amyloid precursor protein by cyclin-dependent kinase 5 . J Neurochem 75:1085-1091.

Ishizawa T, Sahara N, Ishiguro K, Kersh J, McGowan E, Lewis J, Hutton M, Dickson DW, Yen SH (2003) Co-localization of glycogen synthase kinase-3 with neurofibrillary tangles and granulovacuolar degeneration in transgenic mice. Am J Pathol 163:1057-1067.

Jellinger KA (2002) Alzheimer disease and cerebrovascular pathology: an update. J Neural Transm 109:813-836.

Jellinger KA, Bancher C (1998) Neuropathology of Alzheimer's disease: a critical update. J Neural Transm Suppl 54:77-95.

Joutel A, Tournier-Lasserve E (1998) Notch signaling pathway and human diseases. Semin Cell Dev Biol 9:619-625.

Kaytor MD, Orr HT (2002) The GSK3 beta signaling cascade and neurodegenerative disease. Curr Opin Neurobiol 12:275-278.

Klein PS, Melton DA (1996) A molecular mechanism for the effect of lithium on development. Proc Natl Acad Sci USA 93:8455-8459.

Koo E, Sisodia S, Archer D, Martin L, Weidemann A, Beyreuther K, Fischer P, Masters C, Price D (1990) Precursor of amyloid protein in Alzheimer disease undergoes fast anterograde axonal transport. Proc Natl Acad Sci USA 87:1561-1565.

Lee EB, Zhang B, Liu K, Greenbaum EA, Doms RW, Trojanowski JQ, Lee VM (2005) BACE overexpression alters the subcellular processing of APP and inhibits Abeta deposition in vivo. J Cell Biol 168:291-302.

Lee MS, Kao SC, Lemere CA, Xia W, Tseng HC, Zhou Y, Neve R, Ahlijanian MK, Tsai LH (2003) APP processing is regulated by cytoplasmic phosphorylation. J Cell Biol 163:83-95.

Li X, Bijur GN, Jope RS (2002) Glycogen synthase kinase-3beta, mood stabilizers, and neuroprotection. Bipolar Disord 4:137-144.

Lucas JJ, Hernandez F, Gomez-Ramos P, Moran MA, Hen R, Avila J (2001) Decreased nuclear beta-catenin, tau hyperphosphorylation and neurodegeneration in GSK-3beta conditional transgenic mice. EMBO J 20:27-39.

Mai L, Jope RS, Li X (2002) BDNF-mediated signal transduction is modulated by GSK3beta and mood stabilizing agents. J Neurochem 82:75-83.

Mandelkow EM, Drewes G, Biernat J, Gustke N, Van Lint J, Vandenheede JR, Mandelkow E (1992) Glycogen synthase kinase-3 and the Alzheimerlike state of microtubule-associated protein tau. FEBS Lett 314:315-321.

Manji HK, Moore GJ, Chen G (1999) Lithium at 50: have the neuroprotective effects of this unique cation been overlooked? Biol Psychiatry 46:929-940.

Masliah E, Mallory M, Hansen L, Alford M, Albright T, Terry R, Shapiro P, Sundsmo M, Saitoh T (1991) Immunoreactivity of CD45, a protein phosphotyrosine phosphatase, in Alzheimer disease. Acta Neuropathol 83:12-20.

Masliah E, Mallory M, Alford M, DeTeresa R, Iwai A, Saitoh T (1997) Molecular mechanisms of synaptic disconnection in Alzheimer's disease. In: Connections, cognition and Alzheimer's disease (Hyman B, Duyckaerts C, Christen Y, eds), pp 121-140. Berlin: Springer.

McManus EJ, Sakamoto K, Armit LJ, Ronaldson L, Shpiro N, Marquez R, Alessi DR (2005) Role that phosphorylation of GSK3 plays in insulin and Wnt signalling defined by knockin analysis. EMBO J 24:1571-1583.

Mora A, Gonzalez-Polo R, Fuentes J, Soler G, Centeno F (1999) Different mechanisms of protection against apoptosis by valporate and $\mathrm{Li}^{+}$. Eur J Biochem 266:886-891.

Mora A, Sabio G, Risco AM, Cuenda A, Alonso JC, Soler G, Centeno F (2002) Lithium blocks the PKB and GSK3 dephosphorylation induced by ceramide through protein phosphatase-2A. Cell Signal 14:557-562.

Mucke L, Abraham C, Ruppe M, Rockenstein E, Toggas S, Alford M, Masliah E (1995) Protection against HIV-1 gp120-induced brain damage by neuronal overexpression of human amyloid precursor protein (hAPP). J Exp Med 181:1551-1556.

Mucke L, Masliah E, Yu GQ, Mallory M, Rockenstein EM, Tatsuno G, Hu K, Kholodenko D, Johnson-Wood K, McConlogue L (2000) High-level neuronal expression of $\mathrm{A} \beta_{1-42}$ in wild-type human amyloid protein precursor transgenic mice: synaptotoxicity without plaque formation. J Neurosci 20:4050-4058.

Nakashima H, Ishihara T, Suguimoto P, Yokota O, Oshima E, Kugo A, Terada S, Hamamura T, Trojanowski JQ, Lee VM, Kuroda S (2005) Chronic lithium treatment decreases tau lesions by promoting ubiquitination in a mouse model of tauopathies. Acta Neuropathol (Berl) 110:547-556.

Noble W, Planel E, Zehr C, Olm V, Meyerson J, Suleman F, Gaynor K, Wang L, LaFrancois J, Feinstein B, Burns M, Krishnamurthy P, Wen Y, Bhat R, Lewis J, Dickson D, Duff K (2005) Inhibition of glycogen synthase kinase- 3 by lithium correlates with reduced tauopathy and degeneration in vivo. Proc Natl Acad Sci USA 102:6990-6995.

Nonaka S, Chuang DM (1998) Neuroprotective effects of chronic lithium on focal cerebral ischemia in rats. NeuroReport 9:2081-2084.

Nonaka S, Hough CJ, Chuang DM (1998) Chronic lithium treatment robustly protects neurons in the central nervous system against excitotoxicity by inhibiting $N$-methyl-D-aspartate receptor-mediated calcium influx. Proc Natl Acad Sci USA 95:2642-2647.

O’Donnell T, Rotzinger S, Nakashima TT, Hanstock CC, Ulrich M, Silverstone PH (2000) Chronic lithium and sodium valproate both decrease the concentration of myo-inositol and increase the concentration of inositol monophosphates in rat brain. Brain Res 880:84-91.

Ozaki N, Chuang DM (1997) Lithium increases transcription factor binding to AP-1 and cyclic AMP-responsive element in cultured neurons and rat brain. J Neurochem 69:2336-2344.

Pap M, Cooper GM (1998) Role of glycogen synthase kinase-3 in the phosphatidylinositol 3-kinase/Akt cell survival pathway. J Biol Chem 273:19929-19932.

Pei JJ, Tanaka T, Tung YC, Braak E, Iqbal K, Grundke-Iqbal I (1997) Distribution, levels, and activity of glycogen synthase kinase-3 in the Alzheimer disease brain. J Neuropathol Exp Neurol 56:70-78.

Pei JJ, Braak E, Braak H, Grundke-Iqbal I, Iqbal K, Winblad B, Cowburn RF (1999) Distribution of active glycogen synthase kinase 3beta (GSK3beta) in brains staged for Alzheimer disease neurofibrillary changes. J Neuropathol Exp Neurol 58:1010-1019.

Perez M, Hernandez F, Lim F, Diaz-Nido J, Avila J (2003) Chronic lithium treatment decreases mutant tau protein aggregation in a transgenic mouse model. J Alzheimers Dis 5:301-308.

Phiel CJ, Wilson CA, Lee VM, Klein PS (2003) GSK-3alpha regulates production of Alzheimer's disease amyloid-beta peptides. Nature 423:435-439.

Rockenstein E, McConlogue L, Tan H, Power M, Masliah E, Mucke L (1995) Levels and alternative splicing of amyloid $\beta$ protein precursor (APP) transcripts in brains of APP transgenic mice and humans with Alzheimer's disease. J Biol Chem 270:28257-28267.

Rockenstein E, Mallory M, Mante M, Sisk A, Masliah E (2001) Early formation of mature amyloid-b proteins deposits in a mutant APP transgenic model depends on levels of Ab1-42. J Neurosci Res 66:573-582.

Rockenstein E, Mallory M, Mante M, Alford M, Windisch M, Moessler H, Masliah E (2002a) Effects of Cerebrolysin on amyloid-beta deposition in a transgenic model of Alzheimer's disease. J Neural Transm Suppl 327-336.

Rockenstein E, Mallory M, Hashimoto M, Song D, Shults CW, Lang I, Masliah E (2002b) Differential neuropathological alterations in transgenic mice expressing alpha-synuclein from the platelet-derived growth factor and Thy-1 promoters. J Neurosci Res 68:568-578.

Rockenstein E, Adame A, Mante M, Moessler H, Windisch M, Masliah E (2003) The neuroprotective effects of Cerebrolysin trade mark in a transgenic model of Alzheimer's disease are associated with improved behavioral performance. J Neural Transm 110:1313-1327.

Rockenstein E, Mante M, Alford M, Adame A, Crews L, Hashimoto M, Es- 
posito L, Mucke L, Masliah E (2005a) High $\beta$-secretase activity elicits neurodegeneration in transgenic mice despite reductions in amyloid- $\beta$ levels: implications for the treatment of Alzheimer's disease. J Biol Chem 280:32957-32967.

Rockenstein E, Schwach G, Ingolic E, Adame A, Crews L, Mante M, Pfragner R, Schreiner E, Windisch M, Masliah E (2005b) Lysosomal pathology associated with alpha-synuclein accumulation in transgenic models using an eGFP fusion protein. J Neurosci Res 80:247-259.

Rogers J, Luber-Narod J, Styren S, Civin W (1988) Expression of immune system-associated antigens by cells of the human central nervous system: relationship to the pathology of Alzheimer's disease. Neurobiol Aging 9:339-349.

Ryder J, Su Y, Liu F, Li B, Zhou Y, Ni B (2003) Divergent roles of GSK3 and CDK5 in APP processing. Biochem Biophys Res Commun 312:922-929.

Ryder J, Su Y, Ni B (2004) Akt/GSK3beta serine/threonine kinases: evidence for a signalling pathway mediated by familial Alzheimer's disease mutations. Cell Signal 16:187-200.

Ryves WJ, Harwood AJ (2001) Lithium inhibits glycogen synthase kinase-3 by competition for magnesium. Biochem Biophys Res Commun 280:720-725.

Scheff SW, Price DA (2003) Synaptic pathology in Alzheimer's disease: a review of ultrastructural studies. Neurobiol Aging 24:1029-1046.

Selkoe D (1994) Cell biology of the amyloid $\beta$-protein precursor and the mechanisms of Alzheimer's disease. Annu Rev Cell Biol 10:373-403.

Selkoe DJ, Yamazaki T, Citron M, Podlisny MB, Koo EH, Teplow DB, Haass C (1996) The role of APP processing and trafficking pathways in the formation of amyloid beta-protein. Ann NY Acad Sci 777:57-64.

Shaw M, Cohen P (1999) Role of protein kinase B and the MAP kinase cascade in mediating the EGF-dependent inhibition of glycogen synthase kinase 3 in Swiss 3T3 cells. FEBS Lett 461:120-124.

Shiurba RA, Ishiguro K, Takahashi M, Sato K, Spooner ET, Mercken M, Yoshida R, Wheelock TR, Yanagawa H, Imahori K, Nixon RA (1996) Immunocytochemistry of tau phosphoserine 413 and tau protein kinase I in Alzheimer pathology. Brain Res 737:119-132.

Spittaels K, Van den Haute C, Van Dorpe J, Bruynseels K, Vandezande K, Laenen I, Geerts H, Mercken M, Sciot R, Van Lommel A, Loos R, Van Leuven F (1999) Prominent axonopathy in the brain and spinal cord of trangenic mice overexpressing four-repeat human tau protein. Am J Pathol 155:2153-2165.
Su Y, Ryder J, Li B, Wu X, Fox N, Solenberg P, Brune K, Paul S, Zhou Y, Liu F, Ni B (2004) Lithium, a common drug for bipolar disorder treatment, regulates amyloid-beta precursor protein processing. Biochemistry 43:6899-6908.

Sutherland C, Leighton I, Cohen P (1993) Inactivation of glycogen synthase kinase 3 beta by phosphorylation: new kinase connections in insulin and growth-factor signaling. Biochem J 296:15-19.

Takahashi M, Yasutake K, Tomizawa K (1999) Lithium inhibits neurite growth and tau protein kinase I/glycogen synthase kinase-3betadependent phosphorylation of juvenile tau in cultured hippocampal neurons. J Neurochem 73:2073-2083.

Takashima A, Murayama M, Murayama O, Kohno T, Honda T, Yasutake K, Nihonmatsu N, Mercken M, Yamaguchi H, Sugihara S, Wolozin B (1998) Presenilin 1 associates with glycogen synthase kinase-3beta and its substrate tau. Proc Natl Acad Sci USA 95:9637-9641.

Tanzi R, Wenniger J, Hyman B (1993) Cellular specificity and regional distribution of amyloid beta protein precursor alternative transcripts are unaltered in Alzheimer hippocampal formation. Brain Res Mol Brain Res 18:246-252.

Terry R, Peck A, DeTeresa R, Schechter R, Horoupian D (1981) Some morphometric aspects of the brain in senile dementia of the Alzheimer type. Ann Neurol 10:184-192.

Toggas S, Masliah E, Rockenstein E, Mucke L (1994) Central nervous system damage produced by expression of the HIV-1 coat protein gp120 in transgenic mice. Nature 367:188-193.

Torres MA, Eldar-Finkelman H, Krebs EG, Moon RT (1999) Regulation of ribosomal S6 protein kinase-p90(rsk), glycogen synthase kinase3, and beta-catenin in early Xenopus development. Mol Cell Biol 19:1427-1437.

Trojanowski JQ, Lee VM (2000) “Fatal attractions" of proteins. A comprehensive hypothetical mechanism underlying Alzheimer's disease and other neurodegenerative disorders. Ann NY Acad Sci 924:62-67.

Wei H, Qin ZH, Senatorov VV, Wei W, Wang Y, Qian Y, Chuang DM (2001) Lithium suppresses excitotoxicity-induced striatal lesions in a rat model of Huntington's disease. Neuroscience 106:603-612.

Williams RS, Cheng L, Mudge AW, Harwood AJ (2002) A common mechanism of action for three mood-stabilizing drugs. Nature 417:292-295.

Yuan P, Chen G, Manji HK (1999) Lithium activates the c-Jun NH2terminal kinases in vitro and in the CNS in vivo. J Neurochem 73:22992309. 